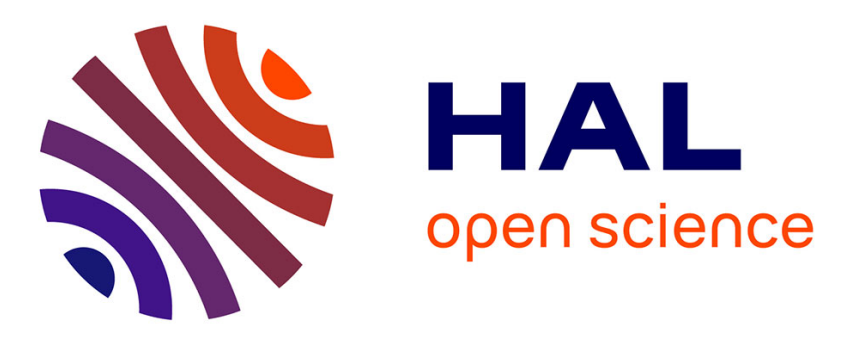

\title{
Analytical calculation of inductances under stator inter-turn short circuits fault condition in operating squirrel cage induction motors
}

Abderrahim Touil, Fatema Babaa, M.R. Ouamane, O. Bennis, Frédéric Kratz, Marouane Hadjami

\section{To cite this version:}

Abderrahim Touil, Fatema Babaa, M.R. Ouamane, O. Bennis, Frédéric Kratz, et al.. Analytical calculation of inductances under stator inter-turn short circuits fault condition in operating squirrel cage induction motors. ELCS 2021, Nov 2021, CAEN, France. hal-03425628

\section{HAL Id: hal-03425628 \\ https://hal.science/hal-03425628}

Submitted on 10 Nov 2021

HAL is a multi-disciplinary open access archive for the deposit and dissemination of scientific research documents, whether they are published or not. The documents may come from teaching and research institutions in France or abroad, or from public or private research centers.
L'archive ouverte pluridisciplinaire HAL, est destinée au dépôt et à la diffusion de documents scientifiques de niveau recherche, publiés ou non, émanant des établissements d'enseignement et de recherche français ou étrangers, des laboratoires publics ou privés. 


\title{
Analytical calculation of inductances under stator inter-turn short circuits fault condition in operating squirrel cage induction motors
}

\author{
A. TOUIL, F. BABAA, M.R. OUAMANE, O. BENNIS, F. KRATZ, M. HADJAMI.
}

\begin{abstract}
The paper presents a strong and realistic model for induction motors including space harmonics of magnetic induction in the sinusoidal distribution model under inter-turn short circuits faults. To represent as much as possible, the reality of the asynchronous machine, we include space harmonics of magnetic induction in sinusoidal distribution model and also an analytical calculation of inductances under shorted fault. Hence, the proposed model is based on coupled magnetic circuit theory. To validate and prove the effectiveness of this model, simulations and experimental results for an induction motor with inter turn short circuit fault, are presented.
\end{abstract}

\section{INTRODUCTION}

Modeling an electric machine is an essential phase for a strong and effective diagnostic. Advances in computer science and software engineering make it possible to achieve efficient modeling and to consider the optimization of electrical machines. Thus, the modeling makes it possible to guide the developments by the exact quantification of the phenomena. A precise model is a valuable contribution because it allows restoring a correct image of what can be observed experimentally, and also, to predict machine behaviors under different defects observation, therefore to make a good diagnosis.

The squirrel cage induction motor is the base on which it stands the industry domain [1] and [5]-[7]. Therefore, it is exposed to many various and undesirable stress pushing these machines to fail caused by the occurrence of fault conditions. Early system diagnosis stands for predictive maintenance techniques to maintain reliability, availability and operational efficiency and reduce operating damage, breakdown losses and maintenance costs. Understanding the behavior of the machines in different states (healthy, faulty) and monitoring the operating characteristics of electrical and mechanical systems within the industrial processes, is the main of academic research [5]-[15].

Several studies showed that there are four types of motor prevalent faults: stator fault, bearing fault, eccentricity, and broken rotor bars fault. Stator fault is the most existing fault

A. Touil is with Electrical Laboratory of Constantine "LEC", University of Constantine 1, ALGERIA, (e-mail: abderrahim.touil@lec-umc.org).

F. Babaa is with Electrical Laboratory of Constantine "LEC", University of Constantine 1, ALGERIA (e-mail: babaa.fatima@yahoo.fr).

M.R. Ouamane is with PRISME Laboratory INSA Centre Val de Loire, Bourges, France (e-mail: mouamane@yahoo.fr).

O. Bennis is with PRISME Laboratory, University of Orleans, 28000

Chartres, FRANCE (e-mail: ouafae.bennis@univ-orleans.fr).

F. Kratz is with PRISME Laboratory INSA Centre Val de Loire, Bourges, France (e-mail: frederic.kratz@insa-cvl.fr).

M. Hadjami is with Electrical Laboratory of Constantine "LEC", University of Constantine 1, ALGERIA, (e-mail: mhadjami@yahoo.fr). (turn-to-turn, coil-to-coil, phase-to-phase short circuits, and phase breakdown). It is also well known that the inter turn fault is related directly to the winding breakdown caused by many factors like the supply voltage transient generated by opening or closing of circuit breakers, variable frequency drives, Thermal stresses created by the overloading, leading to the crash of circuit insulation [15],[19]. It is very important to detect earlier these faults because the failures can lead to an unexpected stop of the industrial process or more energy consumption. So, a lot of research proposes methods to diagnoses faults in induction machines [2] and [4]-[7]. It is necessary for any proposed model should be takes into consideration the behavior of the induction motor in both healthy and faulty states [17]-[26]. Several research studies the techniques of monitoring this fault. In [24] Thomson and al diagnose induction machines, using experimental results to shorted turns faults in low voltage stator windings via frequency components of a motor current signature. Toliyat and Lipo [25] proposed techniques based on the measurements negative sequence current. The negative sequence can also be caused by voltage unbalance like in [17]. In [26], Nandi and Toliyat came with the method based on the technique to detect stator inter-turn faults in induction motors with stator-induced voltages after switch-off.

In this paper, we offer a model and hoping to achieve efficient modeling. From the general mathematical formula of physical phenomenon, we characterize the failure caused by inter turn fault in working conditions of squirrel cage induction machine. Simulations and experimental results are shown at the end of this paper to justify the proposed analytical model.

\section{SYSTEM EQUATIONS}

Equations which describe the squirrel cage induction motor with 3 stator circuits and rotor bars can be written in vector matrix form as follows:

$$
\begin{gathered}
\left\{\begin{array}{c}
{\left[\mathrm{V}_{\mathrm{s}}\right]=\left[\mathrm{R}_{\mathrm{s}}\right] \cdot\left[\mathrm{I}_{\mathrm{s}}\right]+\frac{\mathrm{d}\left[\phi_{\mathrm{s}}\right]}{\mathrm{dt}}} \\
{\left[\begin{array}{c}
{\left[\mathrm{V}_{\mathrm{r}}\right]} \\
\mathrm{V}_{\mathrm{e}}
\end{array}\right]=[\mathrm{O}]=\left[\mathrm{R}_{\mathrm{r}}\right] \cdot\left[\begin{array}{c}
{\left[\mathrm{I}_{\mathrm{r}}\right]} \\
\mathrm{I}_{\mathrm{e}}
\end{array}\right]+\frac{\mathrm{d}\left[\phi_{\mathrm{r}}\right]}{\mathrm{dt}}}
\end{array}\right. \\
\left\{\begin{array}{c}
{\left[\phi_{\mathrm{s}}\right]=\left[\mathrm{L}_{\mathrm{s}}\right] \cdot\left[\mathrm{I}_{\mathrm{s}}\right]+\left[\mathrm{M}_{\mathrm{sr}}\right] \cdot\left[\mathrm{I}_{\mathrm{r}}\right]} \\
{\left[\phi_{\mathrm{r}}\right]=\left[\begin{array}{cc}
{\left[\mathrm{M}_{\mathrm{sr}}\right]^{\mathrm{T}} \cdot\left[\mathrm{I}_{\mathrm{s}}\right]} \\
0
\end{array}\right]+\left[\begin{array}{ll}
{\left[\mathrm{L}_{\mathrm{r}}\right]} & {\left[\mathrm{L}_{\mathrm{e}}\right]^{\mathrm{T}}} \\
{\left[\mathrm{L}_{\mathrm{e}}\right]} & \mathrm{n}_{\mathrm{b}} \cdot \mathrm{L}_{\mathrm{e}}
\end{array}\right] \cdot\left[\begin{array}{c}
{\left[\mathrm{I}_{\mathrm{r}}\right]} \\
\mathrm{I}_{\mathrm{e}}
\end{array}\right] \cdot(2)}
\end{array}\right. \\
\text { With: }\left[\mathrm{L}_{\mathrm{e}}\right]=\left[\begin{array}{lll}
\mathrm{l}_{\mathrm{e}} & \cdots & \left.1_{\mathrm{e}}\right] \text { is a } \mathrm{n}_{\mathrm{b}} \text { vector, } 1_{\mathrm{e}} \text { and } \mathrm{V}_{\mathrm{e}} \text { the }
\end{array}\right.
\end{gathered}
$$
end ring current and voltage respectively. 
For a symmetrical squirrel-cage machine,

$\left[\mathrm{V}_{\mathrm{s}}\right],\left[\mathrm{I}_{\mathrm{s}}\right]$ The stator voltages vector and current vector.

$\left[\mathrm{V}_{\mathrm{s}}\right]=\left[\begin{array}{lll}\mathrm{V}_{\mathrm{sa}} & \mathrm{V}_{\mathrm{sb}} & \mathrm{V}_{\mathrm{sc}}\end{array}\right]^{\mathrm{T}}$ and $\left[\mathrm{I}_{\mathrm{s}}\right]=\left[\begin{array}{lll}\mathrm{I}_{\mathrm{sa}} & \mathrm{I}_{\mathrm{sb}} & \mathrm{I}_{\mathrm{sc}}\end{array}\right]^{\mathrm{T}}$

$\left[\mathrm{I}_{\mathrm{r}}\right]$ : is the rotor loops currents vector.

$$
\left[\mathrm{I}_{\mathrm{r}}\right]=\left[\begin{array}{llll}
\mathrm{I}_{\mathrm{r} 1} & \mathrm{I}_{\mathrm{r} 2} & \cdots & \mathrm{I}_{\mathrm{rn}}
\end{array}\right]^{\mathrm{T}} .
$$

$\left[\mathrm{R}_{\mathrm{s}}\right],\left[\mathrm{R}_{\mathrm{r}}\right]$ : respectively the stator and the rotor matrix resistances.

$$
\left[\mathrm{R}_{\mathrm{s}}\right]=\mathrm{R}_{\mathrm{s}} \cdot 1_{3 * 3}
$$

$\left[\mathrm{L}_{\mathrm{s}}\right]$ is the stator windings inductances matrix, $\left[\mathrm{L}_{\mathrm{r}}\right]$ is the rotor loops currents vector, $\left[\mathrm{M}_{\mathrm{sr}}\right]$ is the mutual inductances matrix, and $\left[\mathrm{M}_{\mathrm{rs}}\right]=\left[\mathrm{M}_{\mathrm{sr}}\right]^{\mathrm{T}}$.

$\left[\phi_{\mathrm{s}}\right],\left[\phi_{\mathrm{r}}\right]$ : total flux linkage by stator and rotor windings, respectively.

The equations describing the mechanical part of the system are:

$$
\begin{gathered}
\mathrm{T}_{\mathrm{e}}=\left[\mathrm{I}_{\mathrm{s}}\right]^{\mathrm{T}} \frac{\partial\left[\mathrm{M}_{\mathrm{sr}}\right]}{\partial \theta}\left[\mathrm{I}_{\mathrm{r}}\right] \\
\mathrm{J} \frac{\mathrm{d} \omega_{\mathrm{r}}}{\mathrm{dt}}=\mathrm{T}_{\mathrm{e}}-\mathrm{T}_{\mathrm{c}} . \\
\frac{\mathrm{d} \theta}{\mathrm{dt}}=\omega_{\mathrm{r}} .
\end{gathered}
$$

Where: $T_{e}$ is the electromagnetic torque produced by the motor, $\mathbf{J}$ is rotor inertia, $\theta$ is the mechanical angle, $\omega_{\mathrm{r}}$ is rotor angular speed and $\mathrm{T}_{\mathrm{c}}$ is the load torque.
The inductances of the system are calculated using the winding function theory given in [10],[11]. The inductance between any two windings $\mathrm{A}$ and $\mathrm{B}$ in any electrical machine could be calculated with:

$$
\mathrm{L}_{\mathrm{AB}}=\mu_{0} \mathrm{rl} \int_{0}^{2 \pi} \mathrm{n}_{\mathrm{A}}(\theta) \mathrm{N}_{\mathrm{B}}(\theta) \mathrm{g}^{-1}(\theta) \mathrm{d} \theta
$$

$\mathrm{r}, 1$ : Average radius of the air gap and axial length of the machine respectively and $\mathrm{g}^{-1}(\theta)$ inverse air-gap function.

$\mathbf{n}_{\mathrm{A}}(\theta), \mathrm{N}_{\mathrm{B}}(\theta)$ : winding functions of windings $\mathrm{A}$ and $\mathrm{B}$.

\section{INTER-TURN SHORT CIRCUITS FAULTS}

As known, among the types of faults happening with the stator the inter-turn short circuit, this defect occurs when there are crashes in the inter-turn insulation [18].

Based on different methods given in the literature [9][16], we deduce the simplest way to represent and simulate the short circuit in a stator phase. We break the proposed analytical development, into two independent circuits. A first named "Healthy" is representing the non-short-circuited conductors of the phase, a second is representing the shorted conductors. In the second circuit, we remark a current flowing through it, which produces an MMF in the opposite direction. The short circuit between the turns decreases the FMM of the defective phase and other healthy phases also change.

The new system of equations with the presence of inter turn short circuit is:

$$
\left[\begin{array}{c}
\mathrm{V}_{\mathrm{sa}} \\
\mathrm{V}_{\mathrm{sb}} \\
\mathrm{V}_{\mathrm{sc}} \\
0
\end{array}\right]=\left[\begin{array}{cccc}
\mathrm{R}_{\mathrm{s}} & 0 & 0 & 0 \\
0 & \mathrm{R}_{\mathrm{s}} & 0 & 0 \\
0 & 0 & \mathrm{R}_{\mathrm{s}} & 0 \\
0 & 0 & 0 & \mathrm{R}_{\mathrm{cc}}
\end{array}\right] \cdot\left[\begin{array}{c}
\mathrm{I}_{\mathrm{sa}} \\
\mathrm{I}_{\mathrm{sb}} \\
\mathrm{I}_{\mathrm{sc}} \\
\mathrm{I}_{\mathrm{cc}}
\end{array}\right]+\frac{\mathrm{d}}{\mathrm{dt}}\left[\begin{array}{c}
\varphi_{\mathrm{sa}} \\
\varphi_{\mathrm{sb}} \\
\varphi_{\mathrm{sc}} \\
\varphi_{\mathrm{cc}}
\end{array}\right]
$$

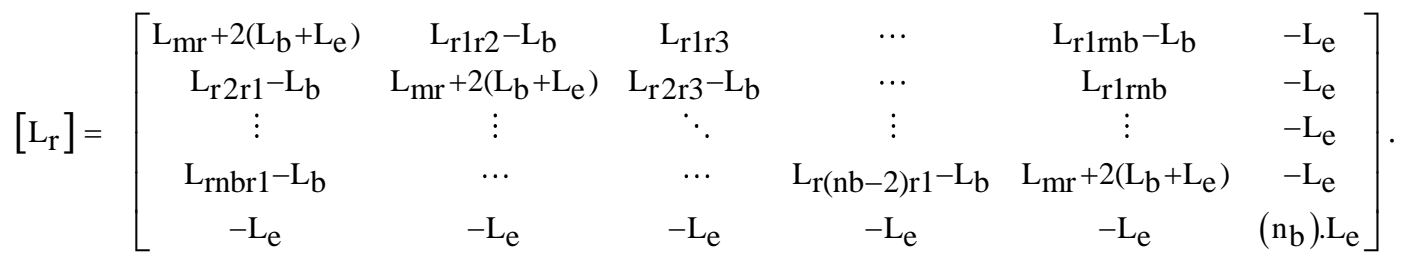


The other equations for rotor voltages as well as the mechanical ones remain the same as for the healthy case seen previously.

\section{INDUCTANCE CALCULATIONS}

For calculation of the inductance, we take into consideration the position of the short-circuited part. For this, we will develop the distribution functions and winding of each turn separately. Conferring to winding function theory [10],[11], the distribution function of a turn is represented here:

$$
\begin{aligned}
& \mathrm{n}_{\mathrm{sp}}(\theta)=\frac{\alpha_{\mathrm{s}}}{2 \pi}+\sum_{\mathrm{h}=1}^{\infty} \frac{2}{\mathrm{~h} \pi} \cdot \sin \left(\mathrm{h} \frac{\alpha_{\mathrm{s}}}{2}\right) . \\
& \cos \left(\mathrm{h}\left(\theta-\frac{\alpha_{\mathrm{s}}}{2}-\frac{2 \pi \mathrm{R}}{\mathrm{N}_{\mathrm{s}}}-\frac{2 \pi \mathrm{K}}{\mathrm{p}}-\frac{(\theta-1) 2 \pi}{3 \mathrm{p}}\right)\right) \\
& \mathrm{N}_{\mathrm{sp}}(\theta)=\sum_{\mathrm{h}=1}^{\infty} \frac{2}{\mathrm{~h} \pi} \cdot \sin \left(\mathrm{h} \frac{\alpha_{\mathrm{s}}}{2}\right) . \\
& \cos \left(\mathrm{h}\left(\theta-\frac{\alpha_{\mathrm{s}}}{2}-\frac{2 \pi \mathrm{R}}{\mathrm{N}_{\mathrm{s}}}-\frac{2 \pi \mathrm{K}}{\mathrm{p}}-\frac{(\theta-1) 2 \pi}{3 \mathrm{p}}\right)\right)
\end{aligned}
$$

The distribution functions of healthy stator windings:

$$
\begin{gathered}
\mathrm{n}_{\mathrm{sq}}\left(\theta_{\mathrm{s}}\right)=\mathrm{C}_{0}+\frac{2 \mathrm{~N}_{\mathrm{t}}}{\mathrm{p} \pi} \sum_{\mathrm{h}=1}^{\infty} \frac{\mathrm{k}_{\mathrm{bo}}}{\mathrm{h}} \\
\cos \left[\mathrm{hp}\left(\theta_{\mathrm{s}}-\theta_{\mathrm{o}}-(\mathrm{q}-1) \frac{2 \pi}{3 \mathrm{p}}\right)\right] \\
\mathrm{N}_{\mathrm{sq}}\left(\theta_{\mathrm{s}}\right)=\frac{2 \mathrm{~N}_{\mathrm{t}}}{\mathrm{p} \pi} \sum_{\mathrm{h}=1}^{\infty} \frac{\mathrm{k}_{\mathrm{bo}}}{\mathrm{h}} \\
\mathrm{N}_{\mathrm{t}}=\mathrm{N}_{\mathrm{c}} \mathrm{N}_{\mathrm{e}} \mathrm{P} \\
\mathrm{K}_{\mathrm{bo}}=\mathrm{K}_{\mathrm{racc}} \mathrm{K}_{\mathrm{dis}}\left[\mathrm{hp}\left(\theta_{\mathrm{s}}-\theta_{0}-(\mathrm{q}-1) \frac{2 \pi}{3 \mathrm{p}}\right)\right] \\
\mathrm{K}_{\mathrm{dis}}=\frac{\sin \left(\mathrm{hp} \pi \frac{\mathrm{N}_{\mathrm{e}}}{\mathrm{N}_{\mathrm{s}}}\right)}{\mathrm{N}_{\mathrm{e}} \cdot \sin \left(\mathrm{hp} \frac{\pi}{\mathrm{N}_{\mathrm{s}}}\right)}, \mathrm{K}_{\mathrm{racc}}=\sin \left(\mathrm{hp} \pi \frac{\mathrm{Q}}{\mathrm{N}_{\mathrm{s}}}\right) \\
\theta_{\mathrm{O}}=\left(\mathrm{N}_{\mathrm{e}}-1+\mathrm{Q}\right) \frac{\pi}{\mathrm{N}_{\mathrm{s}}}
\end{gathered}
$$

$\mathrm{K}_{\text {bo }}$ Winding factor of the $\mathrm{h}^{\text {th }}$ harmonic,

$\mathrm{K}_{\text {dis }}$ Pitch factor of the $\mathrm{h}^{\text {th }}$ harmonic,

$\mathrm{K}_{\text {racc }}$ Distribution factor of the $\mathrm{h}^{\text {th }}$ harmonic,

$\mathrm{N}_{\mathrm{t}}$ Number of stators turns in series, $\mathrm{N}_{\mathrm{c}}$ Number of conductors per stator slot, $\mathrm{N}_{\mathrm{e}}$ Number of slots per pole and per phase, $\mathrm{N}_{\mathrm{s}}$ Number of stator slots, $\theta_{0}$ Angle between stator and rotor reference axes at $\mathrm{t}=0$.

For rotor windings distribution functions:

$$
\begin{array}{r}
\mathrm{n}_{\mathrm{rk}}(\varphi)=\frac{\alpha_{\mathrm{r}}}{2 \pi}+\frac{2}{\pi} \sum_{\mathrm{h}=1}^{\infty} \frac{1}{\mathrm{~h}} \sin \left(\mathrm{h} \frac{\alpha_{\mathrm{r}}}{2}\right) . \\
\cos \left[\mathrm{h}\left(\varphi-\left(\mathrm{k}-\frac{1}{2}\right) \alpha_{\mathrm{r}}\right)\right] \\
\mathrm{N}_{\mathrm{rk}}(\varphi)=\frac{2}{\pi} \sum_{\mathrm{h}=1}^{\infty} \frac{1}{\mathrm{~h}} \sin \left(\mathrm{h} \frac{\alpha_{\mathrm{r}}}{2}\right) \\
\cos \left[\mathrm{h}\left(\varphi-\left(\mathrm{k}-\frac{1}{2}\right) \alpha_{\mathrm{r}}\right)\right]
\end{array}
$$

$\alpha_{\mathrm{r}}=\frac{2 \pi}{\mathrm{n}_{\mathrm{b}}}$ Rotor loop opening.

By using (13) the formula of the winding function theory and the different inductions (stator, rotor, mutual statorrotor), as follow, we have:

Short-circuit magnetization inductance:

$$
\mathrm{L}_{\mathrm{msq}}{ }^{\mathrm{cc}}=\frac{\mu_{0} \mathrm{rl}}{\mathrm{g}_{0}} \mathrm{n}_{\mathrm{cc}}{ }^{2} \sum_{\mathrm{h}=1}^{\infty} \frac{4}{\mathrm{~h}^{2} \mathrm{p} \pi} \sin \left(\mathrm{h} \frac{\alpha_{\mathrm{s}}}{2}\right)^{2} .
$$

Magnetization inductance of a "q" healthy stator phase:

$$
\mathrm{L}_{\mathrm{msq}}=\frac{4 \mu_{0} \mathrm{rl}}{\mathrm{g}_{0}} \mathrm{n}_{\mathrm{t}}{ }^{2} \sum_{\mathrm{h}=1}^{\infty} \frac{\mathrm{k}_{\mathrm{bo}}{ }^{2}}{\mathrm{~h}^{2} \mathrm{p}^{2} \pi}
$$

Mutual inductance between healthy phases of the stator:

$$
\mathrm{L}_{\mathrm{sq} 1 \mathrm{sq} 2}=\frac{4 \mu_{0} \mathrm{rl}}{\mathrm{g}_{0}} \mathrm{n}_{\mathrm{t}}{ }^{2} \sum_{\mathrm{h}=1}^{\infty} \frac{\mathrm{k}_{\mathrm{bo}}{ }^{2}}{\mathrm{~h}^{2} \mathrm{p}^{2} \pi} \cos \left(\mathrm{h}(\mathrm{q} 2-\mathrm{q} 1) \frac{2 \pi}{3}\right) .
$$

Mutual inductance between healthy phase of the stator and short-circuit spirals:

$$
\begin{aligned}
& \mathrm{L}_{\text {scc sq } 2}=\frac{4 \mu_{0} \mathrm{rl}}{\mathrm{g}_{0}} \mathrm{n}_{\mathrm{cc}} \mathrm{n}_{\mathrm{t}} \sum_{\mathrm{h}=1}^{\infty} \frac{\mathrm{k}_{\mathrm{bo}}{ }^{2}}{\mathrm{~h}^{2} \mathrm{p}^{2} \pi} \\
& \cos \left(\operatorname{hp}\left(\theta_{0}-\frac{\alpha_{\mathrm{s}}}{2}-\frac{\mathrm{R} 2 \pi}{\mathrm{N}_{\mathrm{s}}}-\frac{\mathrm{K} 2 \pi}{\mathrm{p}}-\frac{\left(\mathrm{q}_{2}-\mathrm{q}_{\mathrm{cc}}\right) 2 \pi}{3 \mathrm{p}}\right)\right)
\end{aligned}
$$

Mutual inductance between defective stator phase and short-circuit turns:

$$
L_{\text {def } s p c c}=L_{s c c s q 2}-L_{s q m}{ }^{c c} .
$$

With: $n_{s q}{ }^{d e f}(\theta)=n_{s q}(\theta)-n_{c c} * n_{s p}(\theta)$

$\mathrm{N}_{s q}{ }^{d e f}(\theta)=\mathrm{N}_{s q}(\theta)-n_{c c} * N_{s p}(\theta)$

Magnetization inductance of defective phase of the stator:

$$
L_{s q m}{ }^{d e f}=L_{s q m}+L_{s q m}{ }^{c c}-2 * L_{s c c s q 2} .
$$

Mutual inductance between healthy stator phase and defective phase: 


$$
L_{d e f s q 2}=L_{s q 1 s q 2}-L_{s c c s q 2} .
$$

Magnetization inductance of a rotor loop $\mathrm{k}$ is defined by:

$$
L_{m r j}=\frac{\mu_{0} r l}{g_{0}} \frac{4}{\pi} \sum_{\mathrm{h}=1}^{\infty} \frac{1}{h^{2}} \sin \left(h \frac{\alpha_{r}}{2}\right)^{2} .
$$

Mutual inductance between rotor loops:

$$
\begin{aligned}
L_{r j r k}=\frac{4 \mu_{0} r l}{\pi g_{0}} \sum_{\mathrm{h}=1}^{\infty} & \frac{1}{h^{2}} \sin \left(h \frac{\alpha_{r}}{2}\right)^{2} . \\
& \cos \left[h\left(-(j-k) \alpha_{r}\right)\right]
\end{aligned}
$$

Mutual inductances between the short-circuit turns and the rotor loops:

$$
\begin{aligned}
& M_{c c r}=\frac{\mu_{0} r l \cdot n_{c c}}{g_{0}} \sum_{\mathrm{h}=1}^{\infty} \frac{8}{h^{2} p^{2} \pi} \sin \left(h p \frac{\alpha_{r}}{2}\right) \sin \left(h p \frac{\alpha_{s}}{2}\right) \\
& \cos \left[h p\left(\theta_{r}-\frac{\alpha_{s}}{2}-\frac{\mathrm{R} 2 \pi}{N_{s}}-\frac{K 2 \pi}{p}-\frac{\mathrm{q} 2 \pi}{3 p}+\left(k-\frac{1}{2}\right) \alpha_{r}\right)\right]
\end{aligned}
$$
(k):

Mutual inductances between a phase "q" and a rotor loop

$$
\begin{aligned}
& M_{s r}=\frac{\mu_{0} r l}{g_{0}} \frac{4 N_{t}}{\pi p^{2}} \sum_{\mathrm{h}=1}^{\infty} \frac{K_{b o}}{h^{2}} \sin \left(h p \frac{\alpha_{r}}{2}\right) \\
& \cos \left[h \cdot p\left(\theta_{r}-\theta_{0}-(q-1) \frac{2 \pi}{3 p}\right)+h p\left(k-\frac{1}{2}\right) \alpha_{r}\right]
\end{aligned}
$$

Mutual inductance between defective phase and rotor loops:

$$
M_{d e f r}=M_{s r}-M_{c c r} .
$$

\section{Simulations Results}

We introduced the different inductance formulas in the system equations of the induction machine as in [9], [14], [16], These equations can be solved by using fourth-order Runge-Kutta method. We take a simulated machine with 2 poles pairs, 3 phases, $50 \mathrm{~Hz}$ and 22 rotor bars.

Fig. 1 shows the influences of the existence inter turn short circuits faults on the mutual inductances Msr for the defective phase.

Fig. 2 shows waveforms of currents with applied $10 \%$ of inter turn short circuits faults. We used FFT spectrum of stator current to visualize the indices for detection and identification the shorted faults.

Fig. 3 shows the influence of the degree of inter turn short circuits faults applied on the amplitude of some positive and negative frequencies which is clearly responsive of this fault calculated by the formula $f_{c c}=\left[\left(\left(2 n_{b} / \mathrm{p}\right)(1-s) \pm 1\right) \pm 2 k\right] f_{\mathrm{s}}$, with $\lambda=0,1,2 . ., \mathrm{k}=1,2 \ldots$, this frequencies appears in many researches in literature and shows the correctness of our model. Fig. 4, we observe the presence of the negative sequence component frequency. This frequency component appears with any asymmetry in the machine or in the supply voltages.

We also notice the frequencies at $\pm 3 k f_{s}$ as a result by a pulsating torque and a speed oscillation.

In Fig. 5 and Fig. 6, when we applied the inter-turn shorted fault, some frequencies increase. The increase of fault percents provokes the increase of some frequencies. This increase is a significant index of fault presence.

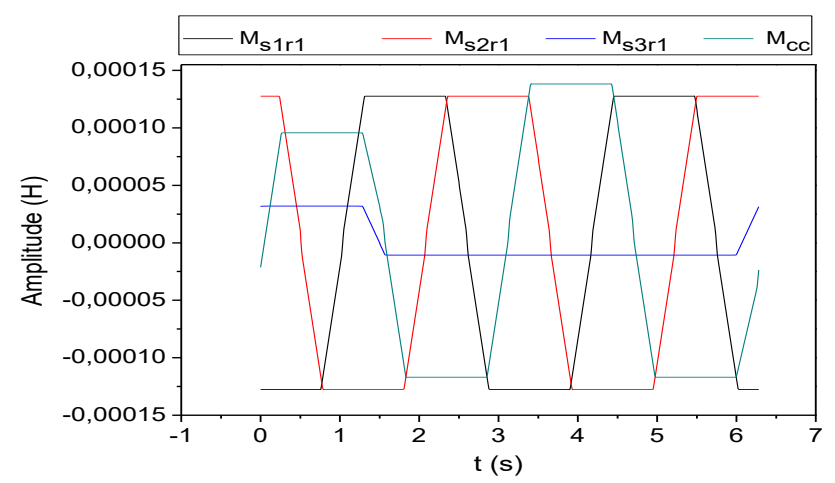

Figure 1. Mutual inductances between stator phases and a rotor loop

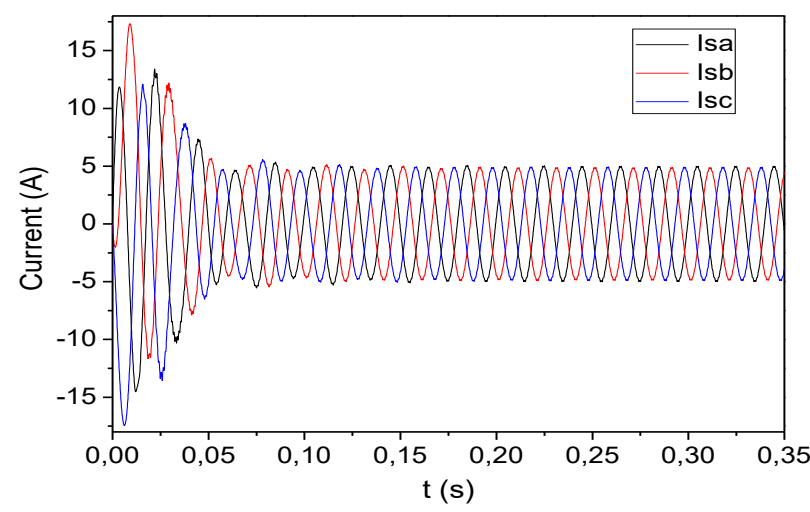

Figure 2. Stator currents including $10 \%$ of inter-turn short circuits.

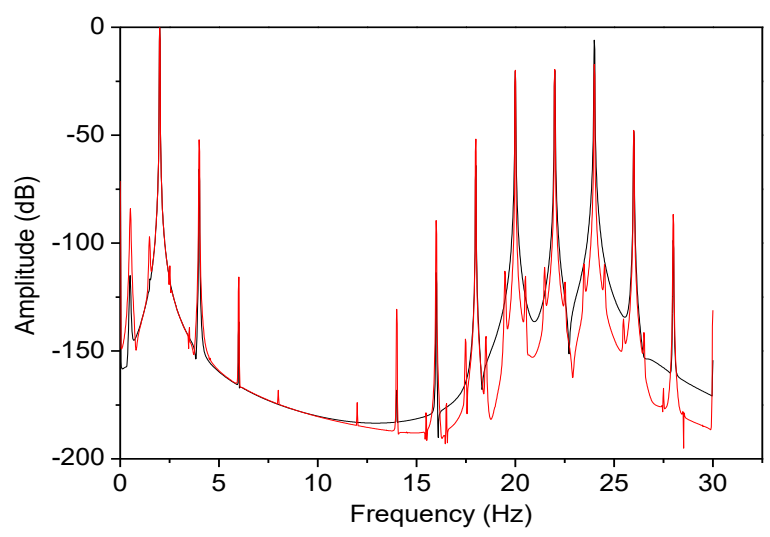

Figure 3. FFT current spectrum under different percent of fault. 


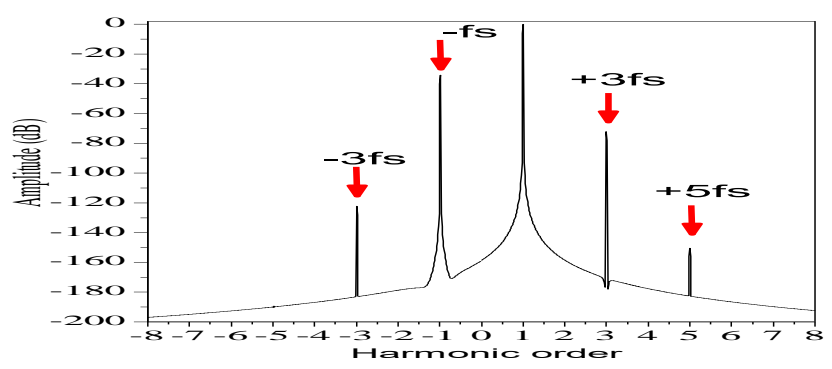

Figure 4. Spectrum of the FFT to the stator current: machine with $2 \%$ of inter-turn short circuit fault, under no load condition

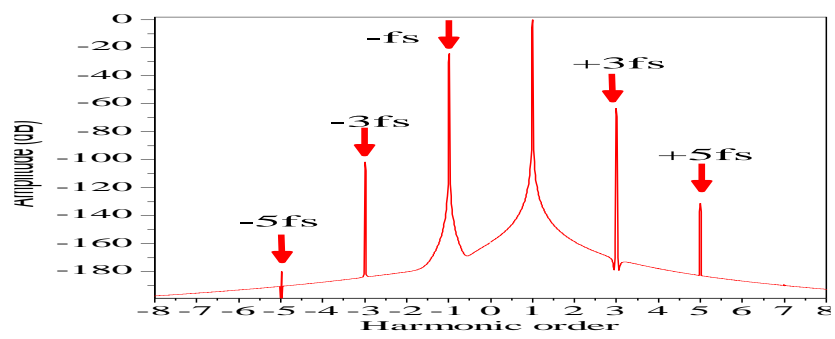

Figure 5. Spectrum of the FFT to the stator current: machine with $10 \%$ of inter-turn short circuit fault, under no load condition

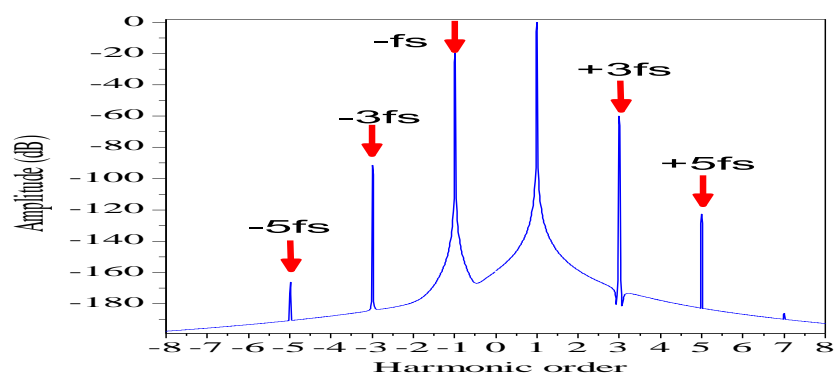

Figure 6. Spectrum of the FFT to the stator current: machine with $20 \%$ of inter-turn short circuit fault, under no load condition

\section{EXPERIMENTAL RESULTS AND DISCUSSION}

Experimental setup permits to study diverse working conditions of the induction motor. Different shorted faults under different load conditions are applied. We use a magnetic powder brake to apply different load torques. The induction machine used in experimental is a "three-phase asynchronous motor, $50 \mathrm{~Hz}, 4$ poles, $1.1 \mathrm{~kW}$, rated at $400 \mathrm{~V}$, $2.95 \mathrm{~A}$ and $1450 \mathrm{rpm}$ ". A re-winding the machine is necessary to choosing previously a number of shorted turns.

Experimentally results confirm the exactitude of the model with the analytical development of inductances. Normalized FFT spectral presentation of the stator current, in healthy condition and with different percent of inter-turn shorted faults under no load conditions, shows same frequencies like in simulation results. In Fig. 4, in healthy situation, we remark the presence of the negative sequence component frequency. This is due to any asymmetry in the machine or, in the supply voltages. We also observe frequencies at $\pm 3 k f_{s}$, as a consequence of a pulsating torque and a speed oscillation. In figure (B), we applied the interturn shorted fault, which provokes the increase of some frequencies. In figure $\mathrm{C}$ and $\mathrm{D}$, we show that some frequencies increase jointly with increasing the fault percent. Therefore, augmentation in frequencies amplitude is significantly proportionally to the fault like those shown in the simulations results.
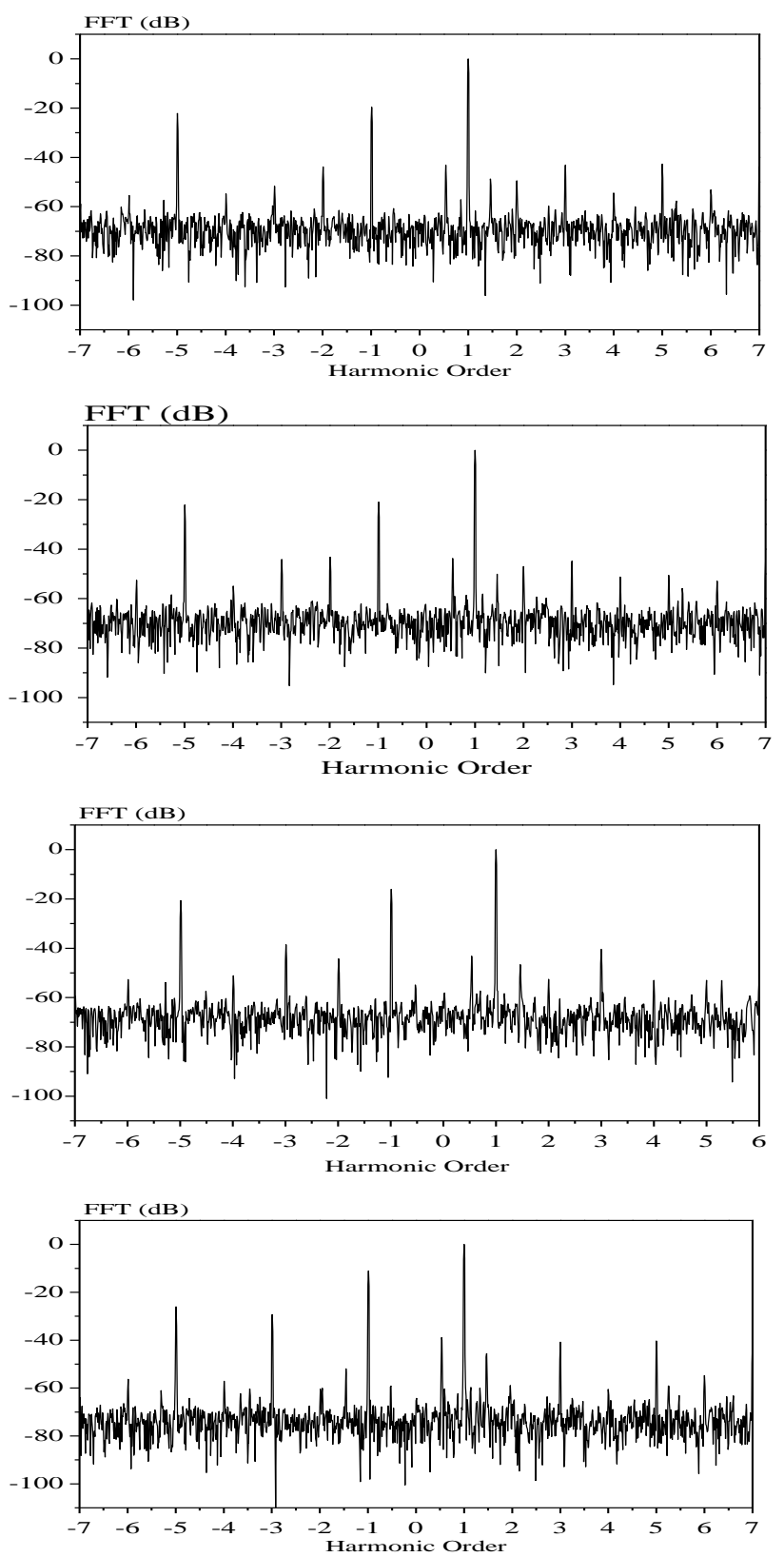

Figure 7. Normalized FFT spectrum of the stator current, in healthy machine (A), with $2 \%$ (B), with 10\% (C) and 20\% (D) of inter turn short circuits faults: no load condition

\section{CONCLUSION}

In this paper, we consider a real distribution of magnetic induction in the air gap, which is represented by the introduction of space harmonics, implies the calculation of the inductances using the winding function approach. After introducing inter-turn short circuits faults, the distribution and winding functions will be modified. So, it is necessary to have a different calculation method from healthy case.

The proposed model is used for the inter-turn short circuit 
fault study, with a precise calculation of the different inductances of the induction machines.

The position of the fault has taken into account, by the model, with precision. Diagnosis of the fault is then more precise. Simulation and experimental results are agreed with the analytical model.

\section{REFERENCES}

[1] A. Bellini, F. Filippetti, C. Tassoni, and G.-A. Capolino, "Advances in diagnostic techniques for induction machines," IEEE Transactions on industrial electronics 55, pp. 4109-26, 2008.

[2] F. Babaa and O. Bennis, "An accurate inter-turn short circuit faults model dedicated to induction motors," The International Journal of Electrical and Computer Engineering (IJECE), Vol. 11, No. 1 February 2021.

[3] F. Babaa, O. Bennis, F. Kratz, and A. Hadri-Hamida, "Combined Electrical Faults Detection and Diagnosis Using Current Signature Analysis," $13^{\text {th }}$ edition of the IEEE International Symposium on. Diagnostics for Electric Machines, Power Electronics and Drives. August 22-25. Dallas TX, pp52-57, SDEMPED 2021.

[4] M. Bouzid, I. Bahloul, and S. Khojet El Khil, "Reliable and Robust Inter-turn Short-CircuitFault Detection in PMSG without confusion with Healthy Operating under Load Unbalance," $13^{\text {th }}$ edition of the IEEE International Symposium on. Diagnostics for Electric Machines, Power Electronics and Drives. August 22-25. Dallas TX, pp372-378, SDEMPED 2021.

[5] Z. He, Zh. Wang, Ch. Duan, and W. Xueqing, "Fault Diagnosis of Inter-turn Short Circuit Faults in Dual Three-Phase PMSM Drives," $13^{\text {th }}$ edition of the IEEE International Symposium on. Diagnostics for Electric Machines, Power Electronics and Drives. August 22-25. Dallas TX, pp388-394, SDEMPED 2021.

[6] E.G Srangas, G. Lerc, H. Razik, A. Soualhi. "Fault Diagnosis, Prognosis and Reliability for electrical Machines and Drives". WILEY-IEEE. pp. 528, 2021.

[7] A.K Jardine, D. Lin and D. Banjevic, "A review on Machinery diagnostics and Prognostics Implementing Condition-based Maintenance, Mechanical systems and signal Processing, Vol. 20, pp. 1483-1510, 2006.

[8] M. Sidki, "Diagnostic Des Defauts De La Machine Asynchrone Par Analyse Spectrale," Revue Interdisciplinaire 1, 2016.

[9] A. S. Fontes, C. A. V. Cardoso, and L. P. B. Oliveira, "Comparison of techniques based on current signature analysis to fault detection and diagnosis in induction electrical motors," In 2016 Electrical Engineering Conference (EECon), pp. 74-79, 2016.

[10] Z. Ye, B. Wu, and N. Zargari, "Modeling and simulation of induction motor with mechanical fault based on winding function method," In 2000 26th Annual Conference of the IEEE Industrial Electronics Society. IECON 2000. 2000 IEEE International Conference on Industrial Electronics, Control and Instrumentation. 21st Century Technologies, vol.4, pp. 2334-39, 2000.

[11] M. Ojaghi, M. Sabouri, and J. Faiz, "Diagnosis methods for stator winding faults in three-phase squirrel-cage induction motors," International transactions on electrical energy systems 24, pp. 891-912, 2014.è

[12] B. Liang, B. S. Payne, A. D. Ball, and S. D. Iwnicki, "Simulation and fault detection of three-phase induction motors," Mathematics and computers in simulation 61, pp. 1-15,2002.

[13] H. Khelfi and S. Hamdani, "Induction Motor Rotor Fault Diagnosis Using Three-Phase Current Intersection Signal," Electrical Engineering 102, pp. 539-48, 1 june 2020.

[14] S. M. A. Cruz and A. J. M. Cardoso, "Stator winding fault diagnosis in three-phase synchronous and asynchronous motors, by the extended Park's vector approach," IEEE Transactions on industry applications 37, pp. 1227-33, 2001.
[15] X. TU, L. A. Dessaint, M. Elkahel, and A. Barry, "Simulation of internal faults in synchronous machines using winding function," in Electrimacs' $02,2002$.

[16] A. L. Constantin, "Detection Based on Stator Current Signature of the Single and Combined Short-Circuit, Broken Bar and Eccentricity Faults in Induction Motors," In 2019 11th International Symposium on Advanced Topics in Electrical Engineering (ATEE), pp. 1-6, 2019.

[17] S. Das, P. Purkait, and S. Chakravorti, "Separating induction Motor Current Signature for stator winding faults from that due to supply voltage unbalances," In 2012 1st International Conference on Power and Energy in NERIST (ICPEN), pp. 1-6, 2012.

[18] A. Stavrou, H. G. Sedding, and J. Penman, "Current monitoring for detecting inter-turn short circuits in induction motors," IEEE Transactions on Energy Conversion 16, pp. 32-37, march 2001.

[19] F. Babaa, A. Khezzar, and M.E.K Oumaamar, "Experimental investigation and comparative study of interturn short-circuits and unbalanced voltage supply in induction machines," Frontiers in Energy 7, pp. 271-78, 2013.

[20] M. Eftekhari, M. Moallem, S. Sadri, and A. Shojaei, "Review of induction motor testing and monitoring methods for inter-turn stator winding faults," In 2013 21st Iranian Conference on Electrical Engineering (ICEE), IEEE, pp. 1-6, 2013.

[21] M. Irhoumah, R. Pusca, E. Lefevre, D. Mercier, and R. Romary, "Detection of the Stator Winding Inter-Turn Faults in Asynchronous and Synchronous Machines Through the Correlation Between Harmonics of the Voltage of Two Magnetic Flux Sensors," IEEE Transactions on Industry Applications 55, pp. 2682-89, 2019.

[22] K. N. Gyftakis, M. Drif, and A. J. M. Cardoso, "Thorough investigation of the third current harmonic in delta-connected induction motors suffering from a stator inter-turn fault," In 2015 IEEE 10th International Symposium on Diagnostics for Electrical Machines, Power Electronics and Drives (SDEMPED), pp. 7-13, IEEE, 2015.

[23] M. Arkan, D. Kostic-Perovic, and P. J. Unsworth, "Modelling and simulation of induction motors with inter-turn faults for diagnostics," Electric Power Systems Research 75, pp. 57-66, 2005.

[24] W. T. Thomson, "On-line MCSA to diagnose shorted turns in low voltage stator windings of 3-phase induction motors prior to failure," In IEMDC 2001. IEEE International Electric Machines and Drives Conference (Cat. No.01EX485), pp. 891-98, 2001.

[25] H. A. Toliyat and T.A. Lipo, "Transient analysis of cage induction machines under stator, rotor bar and end ring faults," IEEE Transactions on Energy Conversion 10, pp. 241-47, June 1995.

[26] S. Nandi and H. A. Toliyat, "Novel frequency-domain-based technique to detect stator interturn faults in induction machines using stator-induced voltages after switch-off ," IEEE Transactions on Industry Applications 38, pp. 101-9, January 2002. 